\title{
Precore Mutant Hepatitis B Virus and Outcome of Chronic Infection and Hepatitis in Hepatitis B e Antigen-Positive Children
}

\author{
CRISTIANA BARBERA, PIERLUIGI CALVO, ALESSANDRA COSCIA, \\ LAURA PERUGINI, GIUSEPPE DASTOLI, ANNA RANDONE, FERRUCCIO BONINO, \\ AND MAURIZIA ROSSANA BRUNETTO \\ Division of Gastroenterology, Pediatric Clinic, Torino, Italy [C.B., A.C.]; Laboratory of the \\ Gastroenterology Department, Molinette Hospital, Torino, Italy (P.C., A.R., F.B., M.R.B.|; \\ Immunohaematology and Transfusion Service, Regina Margherita Hospital, Torino, Italy [L.P.]; \\ and Prodotti Roche Milano S.p.A., Milano, Italy /G.D.I
} \begin{abstract}
ABST
Mutant hepatitis B virus (HBV), responsible for the lack of
hepatitis B virus " $\mathrm{e}$ " antigen (HBeAg) secretion because of a translational stop codon at nuclcotide 1896 of the HBV-DNA precore region ( $\mathrm{HBeAg}$ minus $\mathrm{HBV}$ ), has been detected worldwide in acute and chronic $\mathrm{HBV}$ infections and diseases. HBeAg minus HBV appears to condition the outcome of infection and to be involved in the pathogenesis of hepatitis B. We investigated the mutant prevalence and its clinical implications in 30 hepatitis B surface antigen/ $\mathrm{HBeAg}$-positive children (17 treated with interferon) with chronic hepatitis $B$. Wild-type and $\mathrm{HBeAg}$ minus $\mathrm{HBV}$ were characterized by quantitative oligohybridization assays in sera from 29 children followed up for a mean of 33 mo (12 mo to $9 \mathrm{y}$ ). At admission, 18 children $(62 \%)$ circulated wild-type $\mathrm{HBV}$ alone; mutant HBV became detectable in two of them during the follow-up before $\mathrm{HBeAg} / a n t i-\mathrm{HBe}$ seroconversion. Wild-type and HBeAg minus HBV were detected in 10 children (34.5\%); mutant HBV levels were lower than $20 \%$ of total viremia in four of them and higher in six. Serum HBV-DNA from one child did not hybridize with our probes. $\mathrm{HBeAg}$ minus $\mathrm{HBV}$ was associated with older age $(p<0.009)$ and higher histologic activity $(p<0.069)$. HBeAg/anti-HBe seroconversion oc-
\end{abstract}

curred independently from $\mathrm{HBeAg}$ minus HBV detection; it was observed in six $(37.5 \%)$ of 16 children with wild-type HBV alone and in four $(33.3 \%)$ of 12 children with mixed viremia. In cases with mixed viremia, seroconversion occurred in four $(66 \%)$ of six with $\mathrm{HBcAg}$ minus levels lower than $20 \%$ of total viremia but in none of six with higher levels $(p<0.066)$. These findings suggest that $\mathrm{HBeAg}$ minus $\mathrm{HBV}$ can be detected in chronic HBV carrier children; it has relevant clinical implications and affects the outcome of both HBV infection and disease when its relative prevalence reaches values higher than 20\% of total viremia. (Pediatr Res 36: 347-350, 1994)

HBV, hepatitis B virus

\section{Abbreviations}

anti-HBe, antibody to $\mathrm{HBeAg}$

HBeAg, hepatitis B virus " $\mathrm{e}$ " antigen

HBsAg, hepatitis B surface antigen

ALT, alanine aminotransferase

IgM anti-HBc, antibodies against hepatitis B core antigen of class $\mathrm{M}$

IFN, interferon

gen, genome
HBV mutants unable to secrete $\mathrm{HBeAg}$ have been isolated from both acute and chronic hepatitis $B$ patients worldwide $(1-4)$. The mutation accounting for more than 95\% of HBeAg-defective HBV so far described is a G-A switch at nucleotide 1896 that creates a translational stop codon (1-6). Such a mutant (HBeAg minus HBV) appears to be an important pathogenetic determinant of

Received October 11, 1993; accepted April 18, 1994.

Correspondence: Maurizia Rossana Brunetto and Ferruccio Bonino, M.D., Laboratory of the Gastroenterology Dept. Molinette Hospital, Corso Bramante 88-10126 Torino, Italy.

Supported in part by grants from Prodotti Roche Italia, Milano, and the Comitato Nazionale Ricerche CNR of Italy (contract 92.02300 PF39).
HBV infection in adult patients (7). Mother-to-child transmission of mixed populations of wild-type and $\mathrm{HBeAg}$ minus HBV is associated with acute self-limiting hepatitis and HBV clearance in newborns $(8,9)$. Perinatal infection with wild-type $\mathrm{HBV}$ alone often results in chronic HBV carriership $(9,10)$. High levels of HBV viremia in the absence of liver damage are common in HBs Ag/HBeAg-positive children (11); nevertheless, about two thirds of them clear HBV replication before adulthood with annual $\mathrm{HBe} \mathrm{Ag} /$ anti-HBe seroconversion rates of $10-19 \%(12,13)$. Seroconversion is usually associated with hepatitis exacerbation (12). In adults, $\mathrm{HBeAg}$ to anti-HBe seroconversion follows the loss of immuno- 
tolerance and the onset of the HBV immunoelimination phase, which were found to be associated occasionally with the ex novo $\mathrm{HBeAg}$ minus $\mathrm{HBV}$ detection $(3,14$, 15). However, when mutant HBV reaches levels higher than $20 \%$, it is associated with viral replication persistence (14).

To investigate the relations between $\mathrm{HBe} A g$ minus HBV and the outcome of chronic hepatitis B, we characterized quantitatively the circulating viral populations of $30 \mathrm{HBsAg} / \mathrm{HBe} \mathrm{Ag}$-positive children, followed up for a mean of 33 mo.

\section{METHODS}

Patients. We included in the study 30 consecutive HBsAg-positive children with evidence of chronic HBV infection (lasting for more than $6 \mathrm{mo}$ ). They were followed up at the Pediatric Clinic of the University of Torino for a mean of 33 mo (range 12 mo to $9 \mathrm{y}$ ) with blood controls obtained at least every 3 mo. Their median age was 8 y (ranging from 2 to $14 \mathrm{y}$ ); 15 were males and 15 females. Twenty-seven of them had persistently elevated serum ALT levels (mean value $133 \mathrm{U} / \mathrm{L}$, range 51-801 U/L) and detectable serum IgM anti-HBc and HBV-DNA; the remaining three were asymptomatic with normal liver biochemistry despite viremia levels higher than $10^{7} \mathrm{gen} / \mathrm{Eq} /$ $\mathrm{mL}$. None of them were anti-hepatitis $\mathrm{C}$ virus, antihepatitis D virus, and anti-HIV positive. Seventeen patients were treated with IFN according to the protocol of a controlled multicenter randomized trial (16). Monthly visits were conducted during hepatitis exacerbation or during IFN treatment.

The potential sources of $\mathrm{HBV}$ infections were perinatal transmission from $\mathrm{HBsAg} / \mathrm{HBe} \mathrm{Ag}$-positive mothers in seven cases, household contact in 17 , blood product in one, and unknown in two. Three adopted children were born in geographic areas hyperendemic for HBV infection, and a perinatal transmission cannot be ruled out.

Liver histology. A liver biopsy was available from 16 patients: the histologic diagnoses were consistent with minimal lesions in one patient, chronic persistent hepatitis in 12, and mild chronic active hepatitis in the remaining three.

Assays. Routine blood chemistry tests including a liver function test (AST, ALT, $\gamma$-glutamyltranspeptidase, alkaline phosphatase, serum albumin, gammaglobulins, total bilirubin, and prothrombin time) were done using standard procedures. HBV serologic markers were detected by RIA (AUSRIA II, CORAB, HBe kit, Abbott Laboratories, North Chicago, IL) using 10 Paul Ehrlich Institute units as positive/negative cut-off $[0.200 \mathrm{IMx}$ index value (IMx is a microparticle enzymatic immunoassay) (16)]. HBV-DNA was detected semiquantitatively in whole serum $(150 \mu \mathrm{L})$ by a dot-blot hybridization assay (17). The overall sensitivity of the test was about $10^{5}$ $\mathrm{gen} / \mathrm{Eq} / \mathrm{mL}$. Negative specimens were amplified by polymerase chain reaction using a commercial amplification kit (Cetus Corp., Emeryville, CA) and primers encom- passing the precore and core region. The primer sequences were 5'-GGGGAGGAGATTAGGTTAA-3' (1744-1761) and 5'-GGCAAAAACGAGAGTAACTC-3' (1940-1959), respectively (15). Thirty cycles of amplification were carried out in a thermal cycler (Perkin Elmer Cetus, Emeryville, CA): $95^{\circ} \mathrm{C}$ for $2 \mathrm{~min}(5 \mathrm{~min}$ for the $1 \mathrm{st}$ cycle), $55^{\circ} \mathrm{C}$ for $2 \mathrm{~min}, 72^{\circ} \mathrm{C}$ for $2 \mathrm{~min}$, and final extension at $72^{\circ} \mathrm{C}$ for $10 \mathrm{~min}$. Amplification products were detected by ethidium bromide staining with an overall sensitivity of $10^{4}$ gen. Wild-type and $\mathrm{HBeAg}$ minus HBV were characterized in 104 sera after PCR amplification by an oligohybridization assay as previously reported (14). Amplified DNA $(10 \mu \mathrm{L})$ was spotted on nitrocellulose filters, incubated with ${ }^{32} \mathrm{P} 5^{\prime}$ end-labeled oligonucleotides without mutations (5'-TGGCTTTGGGGCATGGAC-3') or with two nucleotide mutations (5'-TGGCTTTAGGACATGGAC-3') under stringent hybridization and washing conditions, and autoradiographed as reported (14). The sensitivity, specificity, and reproducibility of the assays were controlled by repeated tests and end-point dilution curves of wild-type and $\mathrm{HBeAg}$ minus reference sera (14).

Statistical analysis. Statistical analysis was performed by using $\chi^{2}$, Mann-Whitney U, Fisher's, and Spearman's correlation tests.

\section{RESULTS}

At admission, viremia was detectable by dot-blot hybridization in $24(80 \%)$ of $30 \mathrm{HBs} \mathrm{Ag} / \mathrm{HBeAg}$-positive children. The mean HBV-DNA level was $10^{6} \mathrm{gen} / \mathrm{Eq} / \mathrm{mL}$; the levels ranged between $10^{7}$ and $10^{8} \mathrm{gen} / \mathrm{Eq} / \mathrm{mL}$ in five cases and between $10^{6}$ and $10^{7} \mathrm{gen} / \mathrm{Eq} / \mathrm{mL}$ in five cases and were $10^{6} \mathrm{gen} / \mathrm{Eq} / \mathrm{mL}$ in 13 cases and $10^{5} \mathrm{gen} / \mathrm{Eq} / \mathrm{mL}$ in one case. After PCR amplification, serum HBV-DNA became detectable in five of the remaining six patients; it remained undetectable in one child $(3.3 \%)$ who seroconverted from $\mathrm{HBeAg}$ to anti-HBe during 5 mo follow-up. Circulating viral populations were studied in 29 children: wild-type HBV alone was detected in 18 patients $(62 \%)$, and mixed viral populations of both wild-type and $\mathrm{HBe} A g$ minus HBV were found in $10(34.5 \%)$. HBVDNA amplified from the serum of one child did not hybridize with our probes. $\mathrm{HBeAg}$ minus $\mathrm{HBV}$ levels were lower than $20 \%$ of total viremia in four $(40 \%)$ of 10 children with mixed viral populations and ranged between 20 and $40 \%$ in the remaining six. Baseline serum levels of viral replication (HBV-DNA), virus-induced liver disease (IgM anti-HBc) and liver cell damage (ALT), histology, median age, and sex of children with exclusive wild-type or mixed HBV populations are shown in Table 1 . Children with detectable amounts of $\mathrm{HBe} A \mathrm{~g}$ minus HBV were older than children with exclusive wild-type HBV populations (median age was 10 versus $5 \mathrm{y}, p=0.009, z=2.601$, Mann-Whitney $\mathrm{U}$ test). During the follow-up period, $\mathrm{HBeAg} / \mathrm{anti}-\mathrm{HBe}$ seroconversions, associated with the clearance of serum HBV-DNA and persistent ALT serum level normaliza- 
Table 1. Virologic, clinical and demographic features of 28 children according to circulating $H B V$ population*

\begin{tabular}{lcc}
\hline & \multicolumn{2}{c}{ Viral population } \\
\cline { 2 - 3 } & $\begin{array}{c}\text { Homogeneous } \\
\text { wild-type HBV }\end{array}$ & Mixed \\
\hline Number of patients & $18(10) \dagger$ & $10(7) \dagger$ \\
HBV-DNA (gen/Eq/mL) & $10^{7}$ & $10^{6} \ddagger$ \\
$\quad$ Median value & $10^{4}-10^{\mathrm{\kappa}}$ & $10^{4}-10^{\mathrm{k}} \S$ \\
$\quad$ Range & & \\
IgM anti-HBc & $13 / 18$ & $6 / 8 \|$ \\
$>0.200$ IMx & $88 \mathrm{U} / \mathrm{L}$ & $83 \mathrm{U} / \mathrm{L} \ddagger$ \\
ALT & $23-801$ & $27-245$ \\
Median value & 1 & $3 \uparrow$ \\
Range & 9 & 3 \\
ML & & $10 \mathrm{y}$ \\
CPH & $5 \mathrm{y}$ & $7-14$ \\
CAH & $2-14$ & $5 / 5$ \\
Median age & $8 / 10$ & \\
Range & & \\
Male/female &
\end{tabular}

* IMx, microparticle enzymatic immunoassay; ML, minimal lesions; CPH, chronic persistent hepatitis; $\mathrm{CAH}$, chronic active hepatitis

+ Number of children treated with IFN in parentheses.

$\ddagger$ Any significant difference was found in HBV-DNA levels and ALT values among children with $\mathrm{HBeAg}$ minus levels lower or higher than $20 \%$ of total viremia.

$\S p=0.035, z=2.104$, Mann-Whitney U test.

$\|$ Serum for IgM anti-HBc detection was not available in two patients. I $p=0.069$. tion, occurred in $11(36.6 \%)$ of 30 children, eight of them treated with IFN. The loss of serologic markers of viral replication was observed in eight $(44.4 \%)$ of 18 children with exclusive baseline wild-type viremia. $\mathrm{HBe} \mathrm{Ag}$ minus $\mathrm{HBV}$ became detectable in two of them at the time of the hepatitis flare-ups (ALT levels increased $>2$ SD from the baseline value) that preceded their $\mathrm{HBeAg} / \mathrm{anti}-\mathrm{HBe}$ seroconversion. In one case, $\mathrm{HBe} \mathrm{Ag}$ minus $\mathrm{HBV}$ reached a $20 \%$ relative prevalence; nevertheless, in this child both wild-type and mutant viruses were cleared at the end of a liver cell necrosis episode that lasted about 2 mo. Ten mo later, the patient recovered with $\mathrm{HBsAg} / \mathrm{anti}-\mathrm{HBs}$ seroconversion; this was the only case with complete resolution of $\mathrm{HBV}$ infection among 30 children (Fig. 1). $\mathrm{HBeAg}$ to anti-HBe seroconversion and clearance of viral replication occurred in two $(50 \%)$ of four patients with baseline levels of $\mathrm{HBeAg}$ minus HBV lower than $20 \%$ of total viremia. Instead, serum HBV-DNA remained detectable in six patients with baseline mutant virus levels higher than $20 \%$ of total viremia. In one of them, $\mathrm{HBeAg}$ minus HBV levels increased during the follow-up: a major increment of the relative prevalence of $\mathrm{HBeAg}$ minus $\mathrm{HBV}$ (a shift from 30 to $50 \%$ of total viremia) was observed after a mild liver cell necrosis episode (ALT levels of 140 $\mathrm{U} / \mathrm{L}$ ) that was not associated with changes in the $\mathrm{HBeAg} /$ anti-HBe status.

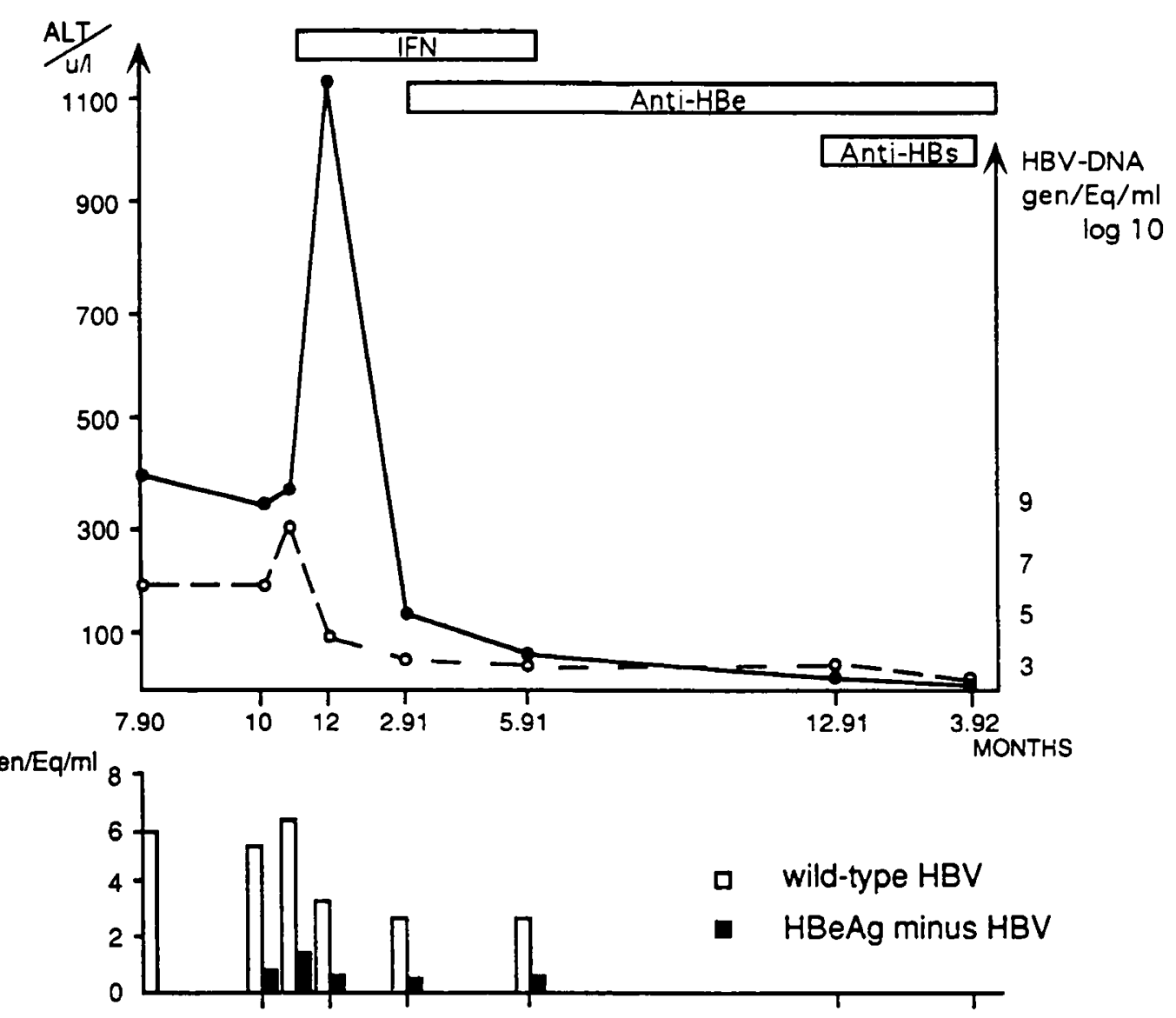

Figure 1. Outcome of chronic hepatitis in a 5-y-old child who seroconverted from $\mathrm{HBeAg}$ during IFN therapy and to anti-HBs $7 \mathrm{mo}$ thereafter. He had wild-type HBV alone at baseline. $\mathrm{HBeAg}$ minus $\mathrm{HBV}$ became detectable before starting IFN treatment, and it reached its highest serum levels at the peak of the ALT flare-up. 
Overall, we found $\mathrm{HBeAg}$ minus HBV (at admission or during the follow-up) in 12 patients. $\mathrm{HBeAg}$ to anti-HBe seroconversion occurred in $66 \%(4 / 6)$ of children with mutant HBV serum levels lower than $20 \%$ or with ex novo $\mathrm{HBeAg}$ minus detection during the follow-up but in none of the children with higher levels of $\mathrm{HBeAg}$ minus viremia $(p<0.066)$.

\section{DISCUSSION}

Chronic HBV infection sustained by both wild-type and $\mathrm{HBe} A \mathrm{~g}$ minus $\mathrm{HBV}$ appears to be a frequent finding in $\mathrm{HBeAg}$-positive children as well as in adults with chronic hepatitis $B$. We found that the proportion of $\mathrm{HBeAg}$-positive children with mixed infections is comparable to that observed in adults $(36.8 \%)(14)$. One third of $\mathrm{HBs} \mathrm{Ag} / \mathrm{HBeAg}$-positive children (10 of $29,34.4 \%$ ) circulated mutant $\mathrm{HBV}$ as a minor viral population at admission, and two additional patients developed detectable levels of $\mathrm{HBeAg}$ minus $\mathrm{HBV}$ during the follow-up. Apparently the presence $(<20 \%$ of total viremia) of $\mathrm{HBeAg}$ minus HBV did not affect the rate of either spontaneous or IFN-induced $\mathrm{HBe} \mathrm{Ag} /$ anti-HBe seroconversion compared with that observed in adults. Ex novo HBV mutant detection during hepatitis flares in two patients with homogeneous baseline wild-type HBV viremia was associated with an efficient virus immunoelimination and virus replication clearance leading to anti-HBe seroconversion and recovery from hepatitis. In contrast, viral replication and liver disease persisted in all children (three of them treated with IFN) with baseline $\mathrm{HBeAg}$ minus HBV levels higher than $20 \%$ of overall viremia. In these patients, $\mathrm{HBeAg}$ minus $\mathrm{HBV}$ appears to have warranted virus persistence under immunopressure, and furthermore, inefficacious immunoelimination attempts determined the mutant virus progressive selection. The $\mathrm{HBeAg}$ minus HBV ability to escape the immunoelimination is confirmed by its higher relative prevalence after the hepatitis flare-ups (15).

Prevalence $(21.4 \%)$ of $\mathrm{HBeAg}$-positive children with elevated mutant HBV levels appears to be slightly higher than that of $\mathrm{HBeAg}$-positive adults (7.8\%) (13). This could be explained by lower immunocompetence of young children compared with adults with a consequent longer-lasting inefficient immunoelimination phase that selects $\mathrm{HBeAg}$ minus HBV. A less competent immunosystem favoring virus persistence and $\mathrm{HBeAg}$ minus HBV selection could determine transition of chronic hepatitis $B$ from the $\mathrm{HBeAg}$ to the anti-HBe form that prevails in adults. Prospective studies of cohorts of $\mathrm{HBeAg}$ positive children, after anti-HBe seroconversion, can answer this question.

In conclusion, the results of the study support the view that $\mathrm{HBeAg}$ minus $\mathrm{HBV}$ plays a relevant role in the pathogenetic mechanisms of chronic HBV infection. Precore heterogeneity of HBV-DNA appears to have rele- vant implications and to condition the outcome of both HBV infection and disease in both children and adults. Ex novo $\mathrm{HBeAg}$ minus $\mathrm{HBV}$ detection is associated with the beginning of the immunoelimination phase, but the inefficiency of clearing the virus can result in mutant selection. When $\mathrm{HBeAg}$ minus serum levels reach values higher than $20 \%$ of total viremia, the rates of spontaneous and IFN-induced recoveries appear significantly reduced.

Acknowledgments. The authors thank Tomoko Mizoguchi of the Virology Department II, National Institute of Health Tokyo, and Luciana Biasotto Torino for the preparation of the manuscript.

\section{REFERENCES}

1. Brunetto MR, Stemler M. Schodel F, Will H, Ottobrelli A, Rizzetto M, Verme G, Bonino F 1989 Identification of HBV variants which cannot produce pre-core derived $\mathrm{HBeAg}$ and may be responsible for severe hepatitis. Ital J Gastroenterol 21:151-154

2. Carman WF, Jacyna MR, Hadziyannis S, Karayannis P, McGarvey MJ Makris A. Thomas J 1989 Mutation preventing formation of hepatitis $B$ e antigen in patients with chronic hepatitis B infection. Lancet 2:588-590

3. Okamoto H, Yotsumo S, Akahane Y, Yamanka T, Miyazaki Y, Sugay Y, Tsuda F, Tanaka T, Miyakawa Y, Mayumi M 1990 Hepatitis B viruses with precore region defect prevail in persistently infected hosts along with seroconversion to the antibody against e antigen. J Virol 64:1298-1303

4. Shafritz DA 1991 Variants of hepatitis B virus associated with fulminant live disease. N Engl J Med 324:1737-1738

5. Raimondo G, Schneider R, Stemler M, Will H 1990 A new hepatitis B virus variant in a chronic carrier with multiple episodes of viral reactivation and acute hepatitis. Virology 179:64-68

6. Tong SP, Diot P, Gripon JS, Vitvitski L, Trepo' C, Guguen-Guillouzo C 1991 In vitro replication competence of a cloned hepatitis B virus variant with a nonsense mutation in the distal pre-C region. Virology 181:733-737

7. Bonino F, Brunetto MR, Purcell RH, Zuckerman AJ 1991 Genetic heteroge neity of hepatitis viruses: clinical implications. J Hepatol 13(suppl 4):1-83

8. Raimondo G, Tanzi E, Brancatelli S, Campo S, Sardo MA, Rodino' G, Pernice M, Zanetti AR 1993 Is the course of perinatal hepatitis B virus infection influenced by genetic heterogeneity of the virus? J Med Virol 40:87-90

9. Milich DR, Jones JE, Hughes JL, Price J, Raney AK, McLachlan A 1990 Is a function of the secreted hepatitis $B$ e antigen to induce immunologic tolerance in utero? Proc Natl Acad Sci USA 87:6599-6603

10. Lee PI, Chang MH, Lee CY, Hsu HY, Chen JS, Chen PJ, Chen DS 1990 Changes of serum hepatitis B virus DNA and aminotransferases levels during the course of chronic hepatitis B virus infection in children. Hepatology $12: 657-660$

11. Bortolotti F, Cadrobbi P, Crivellaro C, Guido M, Rugge M, Noventa F, Calzia R, Realdi G 1990 Long term outcome of chronic type B hepatitis in patients who acquire hepatitis B virus infection in childhood. Gastroenterology 99:805-810

12. Moyes D, Milne A, Waldon F, Waldon J 1993 Liver function of hepatitis B carriers in children. Pediatr Infect Dis J 12:120-125

13. Brunetto MR, Giarin M, Olveri F, Chiaberge E, Baldi M, Alfarano A, Serra A, Saracco G, Verme G, Will H, Bonino F 1991 Wild tipe and e antigen-minus hepatitis B viruses and course of chronic hepatitis. Proc Natl Acad Sci USA $88: 4186-4190$

14. Brunetto MR, Giarin M, Saracco G, Oliveri F, Calvo PL, Capra G, Randone A, Abate ML, Manzini P. Capalbo M, Piantino P, Verme G, Bonino F 1993 Hepatitis $B$ virus unable to secrete " $e$ " antigen and response to interferon of chronic hepatitis B. Gastroenterolgy 105:845-850

15. Barbera C, Bortolotti F, Crivellaro C. Coscia A, Zancan L, Cadrobbi P, Nebbia G, Pillan MN, Lepore L, Parrelta T, Dastoli G, Brunetto MR, Bonino F 1994 Recombinant interferon alpha- 2 a hastens the HBe to anti-HBe seroconversion rate in chronic hepatitis $\mathrm{B}$ children. Hepatology (in press)

16. Brunetto MR, Torrani MR, Oliveri F, Piantino P, Randone A, Calvo PL, Manzini P, Rocca G, Galli C, Bonino F 1993 Monitoring the natural course and response to therapy of chronic hepatitis $\mathrm{B}$ with an automated semiquantitative assay for IgM anti-HBc. J Hepatol 19:431-436

17. Bonino F, Hoyer B, Nelson J, Engle R, Verme G, Gerin J 1981 Hepatitis B virus DNA in the sera of HBsAg carriers: a marker of active hepatitis $B$ virus replication in the liver. Hepatology 1:386-391 